\title{
DETC2007- 35123
}

\section{DESIGN METHODS, TOOLS, AND OUTCOME MEASURES: A SURVEY OF PRACTITIONERS}

\author{
Maria C. Yang \\ Dept. of Mechanical Engineering and Engineering \\ Systems Division \\ Massachusetts Institute of Technology \\ Cambridge, MA 02139 \\ email: mcyang@mit.edu
}

\begin{abstract}
Several tools and methods drawn from research in design and manufacturing have been successfully transplanted into industry. This paper describes a survey conducted of practicing designers and engineers in fields ranging from product development to aerospace to better understand the methodologies and metrics they employ. Preliminary results suggest that respondents found methodologies such as need finding, storyboarding, and brainstorming useful, but were less familiar with approaches such as systematic design, axiomatic design, or TRIZ. There was wide variation in what respondents felt were appropriate design outcome measures, but positive customer feedback in particular was deemed important in evaluating project performance. Finally, a broad range of design tools was cited as useful by respondents, but computer aided drawing applications in particular were rated highly. It is hoped that this survey can be of value in formulating future research goals in design theory and tool development.
\end{abstract}

\section{INTRODUCTION}

One goal of design research is to formulate approaches and tools that will help practicing engineers and designers produce better design results more efficiently and with fewer resources. Academic research has played a major role in the creation of tools such as CAD that have been widely adopted in countless aspects of engineering and design practice [1]. To gain a better sense of how designers and engineers currently in industry viewed design methods and tools, a web-based survey was conducted to gather descriptive statistics on the following:

- What design methods are practitioners aware of and which do they find useful?
A wide range of design methods are taught in the university classroom as well as studied in the laboratory, but which are considered most valuable in real-world projects? This survey asked about 14 design approaches ranging from Axiomatic design [2] and Quality Function Deployment [3] to techniques specific to individual stages of design, such as TRIZ [4] and brainstorming.

- How do practitioners judge whether their projects are successful?

There are many levels on which to assess design outcome. Engineers and designers typically have immediate, measurable performance requirements to meet, but managers may think of satisfying the customer as a higher priority while organizations may look to product sales as a key measure of design success. This survey examined these design outcome measures along with 5 others possible types of project success.

- What tools do practitioners find effective for their work?

Respondents were asked to consider the value of 12 design tools, ranging from paper logbooks and hand sketching to rapid prototyping and software simulation of designs.

In addition, all respondents were asked to provide the methods, tools and outcome metrics they found particularly effective in their own work. The survey also asked about characteristics of respondents' design projects, including the number of team members on the team, the length of project, and the type of design project (incremental, re-design, or new). 


\section{RELATED WORK}

Several researchers have conducted surveys of design practitioners and how they do their work. Osterman [5] examined 694 companies to assess the incidence of "innovative" work practices such as Total Quality Management and the organizational contexts that foster them. ZikaViktorsson and Ingelgard [6] surveyed 144 product development companies to delineate factors in design team members' work environment that are linked to team-based reflective activities. Vredenburg, et al [7] conducted a survey of 103 software user interface designers to gauge the extent to which user-centered design methodologies were adopted in industry.

\section{METHODOLOGY}

The survey was made available via email invitation from December 2006 to January 2007, and was completed by a total of 106 individuals. Initially, a link to the survey was emailed to a list of alumni from the Stanford University product design program and the mechanical engineering department, as well as alumni of the USC industrial engineering department. These initial participants were encouraged to forward the survey to other designers and engineers. Questions were formulated to address the three main research questions, along with demographic information. This initial set of questions was tested on a small pilot group of 4 respondents and then refined based on their feedback. To maximize participation, the survey was limited to 12 questions with the expectation that interested respondents could be contacted in the future for more detailed interviews.

Section 1 of the survey consisted of basic demographic questions regarding the respondent's job title, size of respondent's company, the industry that the respondent worked in, the geographical location of the company, the level of education of the respondent and field of study.

Section 2 of the examined design practice, asking respondents to consider the most recent design project they have worked on while answer questions regarding the type of project, the duration of the project, and project team size. Respondents were then asked to rate their familiarity and use of several engineering and design methodologies, project success metrics, and design tools.

\section{RESULTS \& DISCUSSION}

\section{Respondent Demographics}

\begin{tabular}{|l|r|r|}
\hline & \multicolumn{1}{|c|}{ Resp. } & \multicolumn{1}{c|}{$\%$} \\
\hline Engineer (hardware, software, sys.) & 47 & $44.3 \%$ \\
\hline Project/product manager & 27 & $25.5 \%$ \\
\hline Product designer & 19 & $17.9 \%$ \\
\hline Other & 13 & $12.3 \%$ \\
\hline TOTAL & 106 & $100.0 \%$ \\
\hline
\end{tabular}

Table 1 Job titles of respondents
Table 1 shows the job titles that the respondents felt best described their work. The most common job title (44.3\%) is "engineer," which includes mechanical, aerospace, systems, and software engineering. $25.5 \%$ of the respondents were product or project managers, followed by $17.9 \%$ product designers. Finally, $12.3 \%$ of respondents described themselves with other job titles such as industrial designer, graphic designer/illustrator, academic, architect, and business development.

\begin{tabular}{|l|r|r|}
\hline & Resp. & \multicolumn{1}{c|}{ \% } \\
\hline Aerospace & 30 & $28.3 \%$ \\
\hline Automotive & 1 & $0.9 \%$ \\
\hline Product development/design & 36 & $34.0 \%$ \\
\hline Software/Interaction design/Internet & 9 & $8.5 \%$ \\
\hline Consulting & 2 & $1.9 \%$ \\
\hline Education & 7 & $6.6 \%$ \\
\hline Other & 21 & $19.8 \%$ \\
\hline TOTAL & 106 & $100.0 \%$ \\
\hline
\end{tabular}

Table 2 Industry of respondents

Table 2 lists the primary business of the respondent's companies. The most common are Product development/design (34\%) and Aerospace (28.3\%). "Other" industries include medical/biotech/healthcare $(8.5 \%)$, high tech equipment, architecture, defense, environmental, ocean, and utilities.

\begin{tabular}{|l|r|r|}
\hline & \multicolumn{1}{|c|}{ Responses } & \% of total \\
\hline$<100$ & 43 & $41.3 \%$ \\
\hline $101 \sim 1,000$ & 13 & $12.5 \%$ \\
\hline $1,001 \sim 10,000$ & 16 & $15.4 \%$ \\
\hline$>10,001$ & 32 & $30.8 \%$ \\
\hline TOTAL & 104 & $100.0 \%$ \\
\hline
\end{tabular}

Table 3 Company size

Table 3 shows the two most represented company sizes are very small (less than 100 people) at $41.3 \%$ and very large (greater than 10,000 ) at $30.8 \%$. Two respondents did not answer this question.

\begin{tabular}{|l|r|r|}
\hline & \multicolumn{1}{|c|}{ Responses } & \multicolumn{1}{c|}{ \% of total } \\
\hline US - West Coast & 58 & $54.7 \%$ \\
\hline US - East Coast & 28 & $26.4 \%$ \\
\hline US - South & 4 & $3.8 \%$ \\
\hline US - Midwest & 5 & $4.7 \%$ \\
\hline Europe & 1 & $0.9 \%$ \\
\hline Asia & 1 & $0.9 \%$ \\
\hline Latin America & 0 & $0.0 \%$ \\
\hline Other & 9 & $8.5 \%$ \\
\hline TOTAL & 106 & $100.0 \%$ \\
\hline
\end{tabular}

Table 4 Company location 
Table 4 shows that companies of the respondents were primarily located on the east and west coasts. "Other" locations included "global," "national," and the Middle East.

\begin{tabular}{|l|r|r|}
\hline & \multicolumn{1}{|c|}{ Responses } & \% of total \\
\hline High School & 1 & $0.9 \%$ \\
\hline Bachelors & 40 & $37.7 \%$ \\
\hline Masters & 57 & $53.8 \%$ \\
\hline PhD & 8 & $7.5 \%$ \\
\hline TOTAL & 106 & $100.0 \%$ \\
\hline
\end{tabular}

Table 5 Education level

The majority of respondents had Masters degrees (53.8\%), as well as Bachelors degrees (37.7\%) (Table 5).

\begin{tabular}{|l|r|r|}
\hline & Responses & \% of total \\
\hline Mech. or Aero. eng. & 33 & $31.1 \%$ \\
\hline Industrial engineering & 13 & $12.3 \%$ \\
\hline Electrical engineering & 7 & $6.6 \%$ \\
\hline Computer science & 12 & $11.3 \%$ \\
\hline Industrial design & 5 & $4.7 \%$ \\
\hline Product design & 20 & $18.9 \%$ \\
\hline Graphic design & 1 & $0.9 \%$ \\
\hline Business & 6 & $5.7 \%$ \\
\hline Other & 9 & $8.5 \%$ \\
\hline TOTAL & 106 & $100.0 \%$ \\
\hline
\end{tabular}

\section{Table 6 Degree major}

$31.1 \%$ of respondents' highest degree was in mechanical or aerospace engineering (Table 6). The next most common degree was product design. "Other" majors include materials science and engineering, civil engineering, plastics engineering, manufacturing, architecture, environmental sciences, psychology, and cinema.

\section{Design practice}

Rather than rely on the respondents assessments of their overall design experiences, respondents were asked to consider the most recent design project they worked on. It was thought that these design projects would be most fresh in their memories so that the respondents could speak in the most detail, and that the projects would be reasonably representative of the respondent's design experience. Here, "design project" means one in which the respondent or their team had to create or modify a product or system.

\section{Design output}

How would you characterize the primary output of this design project?

- A physical product
- A piece of software or software interface (such as a website)

- A system, service, or plan (such as a business model)

- Other (please specify)

\begin{tabular}{|l|r|r|}
\hline & \multicolumn{1}{|c|}{ Resp. } & \multicolumn{1}{c|}{ \% } \\
\hline A physical product & 56 & $65.1 \%$ \\
\hline Software or software interface & 15 & $17.4 \%$ \\
\hline A system, service, or plan & 15 & $17.4 \%$ \\
\hline Other & 0 & $0.0 \%$ \\
\hline TOTAL & 86 & $100.0 \%$ \\
\hline
\end{tabular}

Table 7 Design output

As expected, the majority of the participants questioned designed some type of physical product (Table 7), but a sizeable number designed software or systems. It should be noted here that there was a significant drop off in the number of responses from Section 1 to 2 of the survey, from 106 to 86 . The non-respondents were in such fields as aerospace, defense, utilities, environment, education, and business, and it is not known why these individuals did not respond. Of those that created physical products, 26 were in product development, 18 were in the aerospace industry, 1 in consulting, 1 in academics, and the remaining 12 were in other industries.

\section{$\underline{\text { Team size }}$}

How many core people were directly involved with this project?

- 1 (individual project)

- 2 to 10

- 11 to 50

- more than 50

\begin{tabular}{|l|r|r|}
\hline & \multicolumn{1}{|c|}{ Responses } & \% of total \\
\hline 1 (individual project) & 1 & $1.2 \%$ \\
\hline 2 to 10 & 58 & $67.4 \%$ \\
\hline 11 to 50 & 15 & $17.4 \%$ \\
\hline More than 50 & 12 & $14.0 \%$ \\
\hline TOTAL & 86 & $100.0 \%$ \\
\hline
\end{tabular}

\section{Table 8 Number of core design team members}

The majority of the team projects consisted of 2 to 10 members (Table 8), but many other teams had more members. Team size is an important factor as researchers in team dynamics have long posited that teams smaller teams are generally more effective $[8,9]$, although larger, more systemsoriented projects may necessarily require larger team sizes. Of the 12 respondents whose projects were over 50 people, 11 were from the aerospace industry where projects tend to be on a much larger scale than in product development. 


\section{Novelty of design project}

How would you characterize the scope of this design project?

- Incremental design (a modification of an existing design by minor changes. Example: Version 2.1 of a product.)

- Re-design (an overhaul of an existing design. Example: the "new" Volkswagen Beetle, which is a complete re-design of a version from the 1960s.)

- New design (a product or service that did not exist before that also provides substantial novel features or functions. Example: When the Palm Treo cell phone/organizer was first introduced, no other cell phone existed with that type of functionality integration.)

- Other (please specify)

\begin{tabular}{|l|r|r|}
\hline & Responses & \% of total \\
\hline Incremental design & 16 & $18.6 \%$ \\
\hline Re-design & 30 & $34.9 \%$ \\
\hline New design & 39 & $45.3 \%$ \\
\hline Other & 1 & $1.2 \%$ \\
\hline TOTAL & 86 & $100.0 \%$ \\
\hline
\end{tabular}

Table 9 Novelty of design project

Much of design reflects incremental changes to or redesign of existing designs rather than wholly new designs. Surprisingly, most respondents described their projects as new design (Table 9), and only $18.6 \%$ of respondents described their work as incremental. This difference could be due to many reasons. One is that the definition of the types of design were not made clear in the survey. Another is that the respondents were actually working on novel designs. Finally, there may be an individual bias towards the novelty of one's own work. Novelty can be a subjective measure, but there may be a tendency on the part of the designer to believe what they are doing is new.

\section{Project duration}

How long was this project? Please use whole numbers.

years:

months:

weeks:

days:

\begin{tabular}{|l|r|}
\hline Company size & Project duration (years) \\
\hline Large $(>10,001)$ & 3.41 \\
\hline Mid-size $(1,001-10,000)$ & 3.01 \\
\hline Small $(101-1,000)$ & 2.49 \\
\hline Tiny $(<100)$ & 2.22 \\
\hline AVERAGE & 2.78 \\
\hline
\end{tabular}

Table 10 Project duration and company size
The average length of projects for all respondents was 2.78 years. Griffin [10] notes that there is positive relationship between project duration and complexity, and this is born out in this survey (Table 10). The largest firms had the longest project times, while the smallest companies had the shortest.

\section{Familiarity with design methodologies}

Which of the following product or engineering design methods are you familiar with or have used at any time in the past (not only on your last project)?

- Not familiar with this

- Familiar with this but have never used it

- Have used this ONLY in a school exercise or project

- Have used this in a work-related project and found it useful

- Have used this in a work-related project and found it NOT very useful

a) Need finding (user interviews and observation)

b) Benchmarking with comparable products or services

c) Storyboarding

d) Brainstorming

e) House of Quality/Quality Function Deployment (QFD)

f) Axiomatic Design

g) $T R I Z$

h) Design for $X$

i) Failure Modes and Effects Analysis (FMEA)

j) Systematic Design (Pahl and Beitz)

k) Total design (Pugh Concept Selection)

l) Design Structure Matrices

m) Robust Design

n) Extreme (pair) programming

This list of design methodologies was not meant to be exhaustive, but simply representative of relatively well known approaches that are taught in the university classroom, studied by researchers, and/or used in the workplace. Many effective and intellectually important methodologies were not included simply for lack of space on the survey. The mix of methodologies were also selected so that some looked at the overall design process while others were aimed at specific phases in design, in part because it was anticipated that the respondents would work on projects on various phases of design. 


\begin{tabular}{|c|c|c|c|c|c|}
\hline & $\begin{array}{l}\text { Not } \\
\text { familiar }\end{array}$ & $\begin{array}{l}\text { Familiar, } \\
\text { haven't } \\
\text { used }\end{array}$ & $\begin{array}{l}\text { Used } \\
\text { ONLY } \\
\text { in } \\
\text { school }\end{array}$ & $\begin{array}{l}\text { Used } \\
\text { in } \\
\text { work, } \\
\text { NOT } \\
\text { useful }\end{array}$ & $\begin{array}{l}\text { Used } \\
\text { in } \\
\text { work, } \\
\text { useful }\end{array}$ \\
\hline \multirow{2}{*}{$\begin{array}{l}\text { Need- } \\
\text { finding }\end{array}$} & 6 & 15 & 13 & 2 & 50 \\
\hline & $7.0 \%$ & $17.4 \%$ & $15.1 \%$ & $2.3 \%$ & $58.1 \%$ \\
\hline \multirow{2}{*}{$\begin{array}{l}\text { Bench- } \\
\text { marking }\end{array}$} & 2 & 8 & 4 & 0 & 72 \\
\hline & $2.3 \%$ & $9.3 \%$ & $4.7 \%$ & $0.0 \%$ & $83.7 \%$ \\
\hline \multirow{2}{*}{$\begin{array}{l}\text { Story- } \\
\text { boarding }\end{array}$} & 8 & 16 & 14 & 7 & 41 \\
\hline & $9.3 \%$ & $18.6 \%$ & $16.3 \%$ & $8.1 \%$ & $47.7 \%$ \\
\hline \multirow{2}{*}{$\begin{array}{l}\text { Brain- } \\
\text { storming }\end{array}$} & 2 & 0 & 3 & 1 & 78 \\
\hline & $2.4 \%$ & $0.0 \%$ & $3.6 \%$ & $1.2 \%$ & $92.9 \%$ \\
\hline \multirow{2}{*}{ QFD } & 31 & 21 & 17 & 5 & 12 \\
\hline & $36.0 \%$ & $24.4 \%$ & $19.8 \%$ & $5.8 \%$ & $14.0 \%$ \\
\hline \multirow{2}{*}{$\begin{array}{l}\text { Axiom- } \\
\text { atic } \\
\text { Design }\end{array}$} & 70 & 7 & 6 & 0 & 3 \\
\hline & $81.4 \%$ & $8.1 \%$ & $7.0 \%$ & $0.0 \%$ & $3.5 \%$ \\
\hline \multirow{2}{*}{ TRIZ } & 68 & 9 & 7 & 0 & 2 \\
\hline & $79.1 \%$ & $10.5 \%$ & $8.1 \%$ & $0.0 \%$ & $2.3 \%$ \\
\hline \multirow{2}{*}{$\begin{array}{l}\text { Design } \\
\text { for X }\end{array}$} & 64 & 9 & 8 & 0 & 6 \\
\hline & $73.6 \%$ & $10.3 \%$ & $9.2 \%$ & $0.0 \%$ & $6.9 \%$ \\
\hline \multirow{2}{*}{ FMEA } & 19 & 20 & 10 & 5 & 32 \\
\hline & $22.1 \%$ & $23.3 \%$ & $11.6 \%$ & $5.8 \%$ & $37.2 \%$ \\
\hline \multirow{2}{*}{$\begin{array}{l}\text { System- } \\
\text { atic } \\
\text { design }\end{array}$} & 67 & 7 & 9 & 0 & 3 \\
\hline & $77.9 \%$ & $8.1 \%$ & $10.5 \%$ & $0.0 \%$ & $3.5 \%$ \\
\hline \multirow{2}{*}{$\begin{array}{l}\text { Pugh } \\
\text { Concept } \\
\text { Selection }\end{array}$} & 59 & 7 & 7 & 2 & 11 \\
\hline & $68.6 \%$ & $8.1 \%$ & $8.1 \%$ & $2.3 \%$ & $12.8 \%$ \\
\hline \multirow{2}{*}{$\begin{array}{l}\text { Design } \\
\text { Structure } \\
\text { Matrices }\end{array}$} & 59 & 9 & 7 & 0 & 10 \\
\hline & $69.4 \%$ & $10.6 \%$ & $8.2 \%$ & $0.0 \%$ & $11.8 \%$ \\
\hline \multirow{2}{*}{$\begin{array}{l}\text { Robust } \\
\text { Design } \\
\end{array}$} & 45 & 14 & 5 & 1 & 14 \\
\hline & $57.0 \%$ & $17.7 \%$ & $6.3 \%$ & $1.3 \%$ & $17.7 \%$ \\
\hline \multirow{2}{*}{$\begin{array}{l}\text { Extreme } \\
\text { Program- } \\
\text { ming }\end{array}$} & 62 & 12 & 5 & 4 & 3 \\
\hline & $72.1 \%$ & $14.0 \%$ & $5.8 \%$ & $4.7 \%$ & $3.5 \%$ \\
\hline
\end{tabular}

Table 11 Familiarity and contexts of use for fourteen design methodologies. For each design method, the first row lists the number of respondents reporting, and the second row lists the percentage breakdown across responses (total 100\%)

Overall, needfinding, benchmarking, storyboarding, brainstorming, and failure modes and effects analysis were all rated by as more "useful" than not by respondents. It was anticipated that some of these techniques (needfinding, storyboarding, and brainstorming) might be embraced more by smaller, product design focused companies, while others (benchmarking, FMEA) would have greater adoption in larger, systems-focused companies such as aerospace. Breaking down these results by industry, it was found that those in product development (31 respondents), the distribution was nearly the same. However, those in aerospace (27 respondents) had a slightly different view. 12 of the 27 respondents found needfinding and storyboarding "familiar, but not used" while QFD had been used in school. Across both product development and aerospace, the only 2 methodologies that were consistently found useful were benchmarking and brainstorming.

The remaining methods were all rated as "unfamiliar," meaning that respondents had never heard of them either in an academic or work context. Two of these, Quality Function Deployment (QFD) and Robust Design are notable in that there is a relatively large number of respondents who are "familiar, but who have never used" them, suggesting that QFD is reasonably well known, if not widely applied. It is important to point out that methods generally rated as "unfamiliar" is not meant to imply in any way that these methods are not effective or intellectually rich, but simply that the particular sample of respondents were not conversant with them.

In general, there is a relatively small percentage of individuals who have used methods and found them not useful. Since the highest percentage of respondents either found methods useful or were simply not familiar with the method, the implication here is that if respondents are introduced, educated or trained on an effective method, they will find them useful.

The results in Table 11 suggest two somewhat distinct populations of method familiarity: those who have found methods a-d useful in their work, and those who are who are not familiar with methods e-h and j-n. To better understand these disparities, the pairwise Spearman correlations between each design method were calculated and shown in Error! Reference source not found.. The rated level of awareness shown in Table 11 for each method was converted into an integer value so that the rating "not familiar" = 1, "familiar with but never used" $=2$, "used only in school" $=3$, "used in work but not useful" $=4$, and "used in work and useful" $=4$. These last two ratings were assigned the same value of 4 because they could be reasonably assumed to represent the same level of awareness with a method.

The resulting table suggests a cluster of similar ratings for the less structured methods aimed at the very earliest stages of design, in particular understanding user needs and generating concepts. Ratings for needfinding correlated with those for benchmarking, brainstorming, and storyboarding, and with benchmarking and storyboarding. These correlations mean that respondents' awareness of these methods were consistent for each pair of methods. Those unfamiliar with needfinding tended also to be unfamiliar with benchmarking, and vice versa.

Another, much larger cluster of significant correlations appears for the remaining ten design methods. Each of these methods correlates in a statistically significant way with 7 to 9 of the other methods, meaning that respondents who are familiar with one of these methods tend to have the same level of familiarity with several of the others. 


\begin{tabular}{|c|c|c|c|c|c|c|c|c|c|c|c|c|c|}
\hline & $\begin{array}{l}\text { Bench- } \\
\text { marking }\end{array}$ & $\begin{array}{l}\text { Story- } \\
\text { board- } \\
\text { ing }\end{array}$ & $\begin{array}{l}\text { Brain- } \\
\text { storm- } \\
\text { ing }\end{array}$ & QFD & $\begin{array}{l}\text { Axiom- } \\
\text { atic } \\
\text { design }\end{array}$ & TRIZ & DFX & FMEA & $\begin{array}{l}\text { System- } \\
\text { atic } \\
\text { design }\end{array}$ & $\begin{array}{l}\text { Pugh } \\
\text { concept } \\
\text { select- } \\
\text { ion } \\
\end{array}$ & DSM & $\begin{array}{l}\text { Robust } \\
\text { design }\end{array}$ & $\begin{array}{l}\text { Extreme } \\
\text { program- } \\
\text { ming }\end{array}$ \\
\hline $\begin{array}{l}\text { Need- } \\
\text { finding }\end{array}$ & 0.45 & 0.44 & 0.22 & 0.08 & -0.12 & -0.11 & -.13 & 0.01 & -0.12 & 0.03 & 0.00 & -0.11 & 0.06 \\
\hline $\begin{array}{l}\text { Bench- } \\
\text { marking }\end{array}$ & -- & 0.37 & 0.14 & -0.09 & -0.03 & -0.10 & 0.17 & 0.05 & -0.07 & -0.04 & 0.03 & 0.04 & 0.13 \\
\hline $\begin{array}{l}\text { Story- } \\
\text { board- } \\
\text { ing }\end{array}$ & -- & -- & 0.19 & 0.09 & 0.06 & -0.03 & 0.05 & 0.02 & -0.09 & -0.05 & 0.19 & 0.00 & 0.06 \\
\hline $\begin{array}{l}\text { Brain- } \\
\text { storm- } \\
\text { ing }\end{array}$ & -- & -- & -- & 0.01 & -0.13 & -0.14 & 0.02 & 0.21 & -0.12 & -0.03 & -0.05 & -0.12 & -0.08 \\
\hline QFD & -- & -- & -- & -- & 0.27 & 0.33 & 0.24 & 0.37 & 0.27 & 0.47 & 0.43 & 0.33 & 0.19 \\
\hline $\begin{array}{l}\text { Axiom- } \\
\text { atic } \\
\text { design }\end{array}$ & -- & -- & -- & -- & -- & 0.56 & 0.43 & 0.18 & 0.47 & 0.40 & 0.25 & 0.39 & 0.35 \\
\hline TRIZ & -- & -- & -- & -- & -- & -- & 0.47 & 0.07 & 0.32 & 0.37 & 0.18 & 0.34 & 0.41 \\
\hline DFX & -- & -- & -- & -- & -- & -- & -- & 0.14 & 0.35 & 0.29 & 0.32 & 0.31 & 0.40 \\
\hline FMEA & -- & -- & -- & -- & -- & -- & -- & -- & 0.26 & 0.37 & 0.29 & 0.40 & 0.00 \\
\hline $\begin{array}{l}\text { System- } \\
\text { atic } \\
\text { design }\end{array}$ & -- & -- & -- & -- & -- & -- & -- & -- & -- & 0.59 & 0.43 & 0.57 & 0.41 \\
\hline $\begin{array}{l}\text { Pugh } \\
\text { concept } \\
\text { select- } \\
\text { ion }\end{array}$ & -- & -- & -- & -- & -- & -- & -- & -- & -- & -- & 0.55 & 0.49 & 0.41 \\
\hline DSM & -- & -- & -- & -- & -- & -- & -- & -- & -- & -- & -- & 0.43 & 0.32 \\
\hline $\begin{array}{l}\text { Robust } \\
\text { design }\end{array}$ & -- & -- & -- & -- & -- & -- & -- & -- & -- & -- & -- & -- & 0.24 \\
\hline
\end{tabular}

Table 12 Spearman correlations ( $R$ ) between ratings of design methods. For $N=85$, values in bold are significant for $p=0.05$

Respondents also provided 28 other methods, techniques or approaches that they had found useful and were not listed in the survey. The most commonly listed additional methods include:

- $\quad$ Express-test-cycle iteration with users (making quick prototypes to iteratively evaluate a design idea) [11]

- $\quad$ Mind mapping [12]

- Carefully listening to your client to develop a thorough understanding of what they want. May include ethnographic observation

- Decomposition

- Systems Architecting

Other approaches to design that were added by respondents included integrated design process or parallel design, How-why diagrams [13], De Bono's 6 hats [14], and user testing. Techniques aimed at the later, detailed stages of design include dimension and tolerance analysis and statistical test methods.
Respondents also suggested a number of system-level methods, including Functional Analysis, decomposition, Systems Architecting, DoDAF, utility analysis in trade studies, fault trees, requirement flow down trace tools, and Ishikawa fishbone diagrams.

Some respondents entered software-focused approaches, such as operational sequence diagrams, Object Oriented design, and waterfall method for software design. Software interaction techniques include information architecture methods such as cardsorting and use cases.

Perhaps the simplest piece of advice offered by a responded was to talk with "smart people at the whiteboard/sketchpad/CAD station!" which in some sense is related to the philosophy behind extreme programming. 


\section{Project success measures}

Imagine that you have just completed a design project. How do you know that you have a good outcome? Please rank order the 3 key aspects below that, in your opinion, define a successful design project.

- Meets stated customer/client requirements

- Customer/client gives positive feedback

- Design meets performance requirements

- Design is completed within deadline(s)

- Manager/boss gives positive feedback

- Concept is innovative

- $\quad$ Sense of personal pride in design

- $\quad$ Sales increase because of this project

\begin{tabular}{|l|r|}
\hline & $\begin{array}{l}\text { Respondents } \\
\text { ranking as 1st } \\
\text { choice }\end{array}$ \\
\hline $\begin{array}{l}\text { Meets stated customer/client } \\
\text { requirements }\end{array}$ & $\mathbf{2 0}$ \\
\hline Customer/client gives positive feedback & $\mathbf{2 7}$ \\
\hline $\begin{array}{l}\text { Design meets performance } \\
\text { requirements }\end{array}$ & $\mathbf{1 5}$ \\
\hline Design is completed within deadline(s) & 2 \\
\hline Manager/boss gives positive feedback & 1 \\
\hline Concept is innovative & 1 \\
\hline Sense of personal pride in design & 4 \\
\hline Sales increase because of this project & 13 \\
\hline
\end{tabular}

\section{Table 13 Rankings of successful design outcomes}

Respondents were asked to rank order the top 3 criteria for defining a successful design project from a list. This list, while not exhaustive, represented design success from several viewpoints: the customer, the product, management, sales, and the designer. Table 13 shows the number of respondents that rated each criteria as their top choice. "Customer/client gives positive feedback" emerged as a key outcome measure, followed by "meets stated customer/client requirements" and "design meets performance requirements." While the top 2 choices seem nearly identical at the outset, there is a subtle implicated distinction. Stated customer requirements can be met while not compelling the customer to give positive feedback. It may also be the case that a client gives positive feedback even if the client's requirements are not met.

Respondents provided approximately 15 additional criteria for success including, and several respondents had overlap in their criteria. The most commonly given additional success criteria were, in descending order:

- $\quad$ Staying within budget targets and constraints
- $\quad$ Positive public response to the product and company, including good product reviews and product "buzz"

- High product reliability

- End user satisfaction with the product

- Project is a learning experience for the design team

- Project generates follow-on work from client/customer

- The ability of project to generate intellectual property

Some of the other success factors less commonly given include the impact of the project on the client's professional success within his or her own organization, the profit realized per unit of design time (return on design time), designs that are so innovative that they are disruptive and create new categories of products, staying power of a design, design integrity (appropriate use of materials and respect for the environment), and product safety.

One respondent commented on the difficulty of defining design metrics that non-designers in his or her organization could relate to, such as sales or revenue measures.

\section{Design tools}

What are the 3 most important tools you use to support or facilitate your design work? Please rank order your choices.

- Paper logbooks

- Electronic logbooks/wikis

- Sketching by hand

- Computer aided drawing and design tools - CAD

- Prototyping or mockups by hand

- $\quad$ Rapid prototyping (eg, layered manufacturing)

- Software simulation of designs

- Internet research tools (the Web)

- Communication tools (email, chat, conferencing)

- External consultants (such as design firms or factories)

- Project costing tools

- Project management or planning tools 


\begin{tabular}{|l|r|}
\hline & $\begin{array}{l}\text { Respondents } \\
\text { ranking as 1st } \\
\text { choice }\end{array}$ \\
\hline Paper logbooks & 3 \\
\hline Electronic logbooks/wikis & 4 \\
\hline Sketching by hand & $\mathbf{8}$ \\
\hline $\begin{array}{l}\text { Computer aided drawing and design } \\
\text { tools - CAD }\end{array}$ & $\mathbf{2 7}$ \\
\hline Prototyping or mockups by hand & 4 \\
\hline $\begin{array}{l}\text { Rapid prototyping (eg, layered } \\
\text { manufacturing) }\end{array}$ & 2 \\
\hline Software simulation of designs & 7 \\
\hline Internet research tools (the Web) & $\mathbf{1 7}$ \\
\hline $\begin{array}{l}\text { Communication tools (email, chat, } \\
\text { conferencing) }\end{array}$ & 1 \\
\hline $\begin{array}{l}\text { External consultants (such as design } \\
\text { firms or factories) }\end{array}$ & 0 \\
\hline Project costing tools & 6 \\
\hline $\begin{array}{l}\text { Project management or planning } \\
\text { tools }\end{array}$ & \\
\hline
\end{tabular}

\section{Table 14 Rankings of useful design tools}

Not surprisingly, CAD tools were rated highly as useful tools for design (Table 14). The second highest rated tool were communication and internet tools, which are not designspecific, but clearly necessary for design. Third highest rated was sketching by hand, which, combined with the relevance of CAD tools, points up the importance of visually-focused design tools.

Several respondents provided additional tools in their surveys, but there was little consensus among these save for several references to system architecting tools such as requirements and functional analysis. There were two additional comments about the design process worth mentioning in this paper. The first states that systematic design methods give reliable, if not necessarily innovative results. The second is that the organizational, personnel, and managerial issues associated with design tend to overshadow any of the actual design itself. These two comments are telling because they give a sense of how the efforts of designers (and their methods and tools) are understood in a larger organizational context.

\section{CONCLUSIONS AND FUTURE WORK}

The goal of this survey was primarily to gather descriptive statistics on what methods and tools designers are familiar with and use in their work. If one were to look at the average responses to the survey question, the average project would be to develop a physical product using a small design team. The project would be a novel design and would last 2-3 years.

Of the design methods surveyed, needfinding, benchmarking, storyboarding, and brainstorming had the highest awareness, while other approaches were less familiar to respondents. In general, however, no method had more than a few percent of respondents say that that they had "used it, but found not useful." It is notable that these respondents familiarity with design methods can be divided into two groups: those with similar levels of familiarity with very early stage methods such as needfinding, brainstorming, storyboarding and benchmarking, and those with similar levels of familiarity with the remaining ten methods, suggesting key divisions in the types of respondents observed.

Researchers often think of how to make methodologies more useful to designers, but this finding suggests that when these designers do learn about a particular method, they generally find it useful rather than not useful, and that issues of training and education are key to making design methodologies gain acceptance, rather than improving them.

As expected, $\mathrm{CAD}$, communication tools, and sketching by hand were all rated highly as useful design tools.

This survey has several limitations in that it does not explain why the designer/engineer finds a method or tool useful or not. It also examined a relatively small sample of engineers and designers concentrated in product design and aerospace. Engineering design, of course, encompasses many other important fields that were not well represented in this survey, such as automotive and medical. More detailed results could be obtained by looking at larger samples of people across these and other additional fields.

Future work involves a larger scale study following the lines suggested by this preliminary survey. This would include observation of a larger population of designers and engineers which would allow for even richer and more comprehensive analysis of responses.

\section{ACKNOWLEDGMENTS}

This material is based upon work supported in part by the National Science Foundation under Award DMI-0547629. Any opinions, findings, and conclusions or recommendations expressed in this material are those of the author and do not necessarily reflect the views of the National Science Foundation. The author gratefully acknowledges the responses of the survey participants, the technical assistance of Fan Jia of the University of Southern California, and helpful discussions with Haifeng Ji of the University of Southern California, and Tomonori Honda and Francesco Ciucci of the California Institute of Technology.

\section{REFERENCES}

[1] Szykman S., Sriram R.D., and Regli W.C. The Role of Knowledge in Next-generation Product 
Development Systems. Journal of Computing and

Information Science in Engineering, 2001, 1(1), 3-11.

[2] Suh N.P. The principles of design, 1990 (Oxford University Press, New York, NY).

[3] Akao Y. Quality Function Deployment, 1990

(Productivity Press, Cambridge, MA).

[4] Altshuller G.S., Shulyak L., and Rodman S. The innovation algorithm : TRIZ, systematic innovation and technical creativity, 1999 (Technical Innovation Center, Inc., Worcester, Mass).

[5] Osterman P. How Common is Workplace Transformation and Who Adopts it? Industrial and Labor Relations Review, 1994, 47(2), 173-188.

[6] Zika-Viktorsson A. and Ingelgard A. Reflecting activities in product developing teams: conditions for improved project management processes. Research in Engineering Design, 2006, 17(2), 103-111.

[7] Vredenburg K., et al. A survey of user-centered design practice. Computer-Human Interaction (CHI) Letters, 2002, 4(1).

[8] Katzenbach J.R. and Smith D.K. The Wisdom of Teams: Creating the High-Performance Organization, 1993 (Harvard Business School Press, Boston, MA).

[9] Thompson L. Making the Team: A Guide for Managers, 2004 (Pearson Education, Upper Saddle River, NJ).

[10] Griffin A. The Effect of Project and Process Characteristics on Product Development Cycle Time. Journal of Marketing Research: Special Issue on Innovation and New Products, 1997, 34(1), 24-35.

[11] McKim R.H. Experiences in Visual Thinking, 1980 (PWS Publishers, Boston, MA).

[12] Buzan T. The Mind Map Book, 1991 (Penguin, New York).

[13] Cross N. Engineering Design Methods: Strategies for product development, 1994 (John Wiley \& Sons,

[14] DeBono E. Six Hats Thinking, 1985 (Little, Brown and Co, Boston, MA). 